\title{
Erratum \\ Authentic Movement: Essays by Mary Stark Whitehouse
}

\author{
Beth Lucchi
}

\section{Erratum to: Am J Dance Ther DOI 10.1007/s10465-007- 9026-7}

The name of the author was omitted from the table of contents page and from the book review.

The online version of the original article can be found under doi: $10.1007 / \mathrm{s} 10465-007-$ 9026-7.

Correspondence should be directed to Beth Lucchi, Luke-Dorf Inc., 11895 SW Greenburg Road, Tigard, Washington County, OR, 97223, USA; e-mail: welldancer19@msn.com. 